JKAU: Met., Env. \& Arid Land Agric. Sci., Vol. 23, No. 2, pp: 31-53 (2012 A.D./1433 A.H.)

DOI: $10.4197 /$ Met. 23-2-3

\title{
Trends of Ambient Concentrations of Gaseous Air Pollutants in Almadinah Al Menawwarah, Central Area, Saudi Arabia
}

\author{
Hesham A. Al-Jeelani \\ Department of Environmental Sciences, Faculty of Meteorology, \\ Environment \& Arid land Agriculture, King Abdulaziz University
}

\begin{abstract}
Nitrogen monoxide (NO), nitrogen dioxide $\left(\mathrm{NO}_{2}\right)$, nitrogen oxides $\left(\mathrm{NO}_{\mathrm{x}}\right)$, sulfur dioxide $\left(\mathrm{SO}_{2}\right)$, ozone $\left(\mathrm{O}_{3}\right)$, carbon monoxide (CO), methane $\left(\mathrm{CH}_{4}\right)$ and non-methane hydrocarbons (NMHCs) were measured in Almadinah Al Menawwarah, Saudi Arabia. From Ramadan to Hajj season (October, 2005 - January, 2006) daily average concentrations of $\mathrm{NO}, \mathrm{NO}_{2}, \mathrm{NO}_{\mathrm{x}}, \mathrm{SO}_{2}, \mathrm{O}_{3}, \mathrm{CO}, \mathrm{CH}_{4}$ and NMHCs, were $0.055,0.040,0.095,0.011,0.009,2.82,3.83$ and 1.12 ppm, respectively. The $\mathrm{SO}_{2} / \mathrm{NO}_{\mathrm{x}}$ and $\mathrm{SO}_{2} / \mathrm{NO}_{2}$ concentration ratios were 0.12 and 0.28 , respectively, suggesting that the mobile emissions are the predominant sources within the study area. The diurnal variations of $\mathrm{NO}, \mathrm{NO}_{2}, \mathrm{NO}_{\mathrm{x}}, \mathrm{SO}_{2}, \mathrm{CO}, \mathrm{NMHCs}$ concentrations were similar and showed two daily peaks, in the morning and late evening. These peaks concentrations are linked to traffic density, boundary layer mixing processes and chemical processes in the atmosphere. The diurnal cycles of $\mathrm{O}_{3}$ concentrations revealed a uni-modal peak in the mid-day time. The highest concentrations of the measured pollutants were found in Ramadan and Hajj seasons, due to increasing human activities. Significant positive correlation coefficients $(p<0.05)$ were found between $\mathrm{NO}, \mathrm{NO}_{2}, \mathrm{NO}_{\mathrm{x}}, \mathrm{NMHCs}$ and $\mathrm{CO}$, and also between $\mathrm{SO}_{2}$ and $\mathrm{NO}, \mathrm{NO}_{2}, \mathrm{NO}_{\mathrm{x}}, \mathrm{NMHCs}$ and $\mathrm{CH}_{4}$. Significant negative correlation coefficients were found between $\mathrm{O}_{3}$ concentrations and $\mathrm{NO}_{2}$. These results indicate that an increase in $\mathrm{O}_{3}$ level is associated with a drop in the concentration of $\mathrm{NO}_{2}, \mathrm{CO}$ and NMHCs.

Keywords: Gaseous Air Pollutants, Nitrogen Monoxide, Nitrogen Dioxide, Nitrogen Oxides, Sulfur Dioxide, Ozone, Carbon Monoxide, Methane, Non-Methane Hydrocarbon, Almadinah Al Menawwarah, Saudi Arabia.
\end{abstract}




\section{Introduction}

High rate of industrialization/urbanization process, especially in developing countries, leads to increase in the emission of many types of air pollutants due to fossil fuel combustion. Air pollutants, once emerged from a variety of sources are subject to mixing, dispersion, transport and complex series of chemical interaction and physical transformation processes in urban atmospheres. Nitrogen monoxide (NO), nitrogen dioxide $\left(\mathrm{NO}_{2}\right)$, sulfur dioxide $\left(\mathrm{SO}_{2}\right)$, carbon monoxide $(\mathrm{CO})$ and volatile organic compounds (VOCs) are the most important groups of air pollutants in the urban atmosphere because they can cause significant risk to human health and play an important role in atmospheric photochemistry. These photochemical reactions transform primary air pollutants into secondary air pollutants. The environmental effects of these secondary pollutants are associated with acidification of precipitation, visibility reduction and have deleterious effects on human health and plants.

Oxides of nitrogen, $\mathrm{NO}_{\mathrm{x}}\left(\mathrm{NO}_{2}\right.$ and $\left.\mathrm{NO}\right)$, contributes to a wide range of environmental effects including the formation of acid rain, particulate and gaseous nitrate and regional haze, eutrophication of aquatic ecosystems, and elevated ozone $\left(\mathrm{O}_{3}\right)$ concentrations with resulting impacts on health and agriculture (Matsumoto and Tanaka, 1996; Matsumoto, et al., 1998; Khoder, 2002 and Mauzerall et al., 2005). $\mathrm{NO}_{2}$ is consistently associated with adverse health effects at relatively low levels of long-term average exposure(European Commission, 1997; $\mathrm{WHO}, 2003$ and 2005). The major contributor to $\mathrm{NO}_{\mathrm{x}}$ concentrations in urban areas is road traffic (Jraiw 2002; Shrestha et al., 2005 and CARB, 2006), and it can be used as a tracer of road traffic emissions in urban areas (Lewne et al., 2004). $\mathrm{NO}_{2}$ is formed during the combustion of fossil fuel through the oxidation of atmospheric nitrogen and of nitrogen from certain fuels such as coal and oil (WHO, 1997). It originates from both primary and secondary sources (AQEG, 2004). It is mainly a secondary pollutant since in most ambient situations $\mathrm{NO}$ is emitted and transformed into $\mathrm{NO}_{2}$ in the atmosphere through photochemical processes (Jenkin and Clemitshaw, 2000). However, some studies have shown that $\mathrm{NO}_{2}$ is also emitted as a primary pollutant to a certain extent (PORG, 1997 and Carslaw and Beevers, 2004 and 2005). 
The major health impacts of $\mathrm{SO}_{2}$ include effects on breathing, respiratory illness, weakness of lung defenses, increase in the effects of existing respiratory and cardiovascular disease, and death (Henry and Heinke, 1996 and USEPA 2008). In addition, atmospheric oxidation of $\mathrm{SO}_{2}$ by hydroxide radical $(\mathrm{OH}), \mathrm{O}_{3}$ and hydrogen peroxide $\left(\mathrm{H}_{2} \mathrm{O}_{2}\right)$ contributes to acid deposition and sulfate formation (Finlayson-Pitts and Pitts, 2000 and USEPA, 2008).The major source of $\mathrm{SO}_{2}$ is the combustion of fossil fuels containing sulfur, in particular from power stations burning coal and heavy fuel oil (Afif et al., 2008). Although road transport is a minor source of $\mathrm{SO}_{2}$ at the national level, it can be important in some urban areas, especially alongside busy roads (Holgate et al., 1999).

Carbon monoxide plays an important role in tropospheric chemistry, as it serves to produce $\mathrm{O}_{3}$ and affects $\mathrm{O}_{3}$ concentrations by its effect on $\mathrm{OH}$ and $\mathrm{HO}_{2}$ concentrations (Badarinath et al., 2007). Atmospheric oxidation of $\mathrm{CO}$ leads to $\mathrm{O}_{3}$ formation or destruction, depending upon the NO concentration (Warneck, 1988). The reaction of CO with OH radicals is the primary removal process from the atmosphere. Through this mechanism, $\mathrm{CO}$ acts as a major precursor to photochemical ozone (Crutzen, 1974). Biomass burning, combustion of fossil fuels, and oxidation of hydrocarbons are the major sources of atmospheric CO (Han and Naeher, 2006; Zimmerman et al., 1978; Crutzen et al., 1979; Brewer et al., 1984; Hatakeyama et al., 1991 and CARB, 2006). High concentrations of CO generally occur in areas with heavy traffic (Ali and Athar, 2008). The point sources of CO emission also include industrial processes, non-transportation fuel combustion.

Volatile organic compounds (VOCs), mainly non-methane hydrocarbons (NMHCs), are the key players in the formation of tropospheric $\mathrm{O}_{3}$ and secondary organic aerosol (Seinfeld and Pandis, 2006). Sources of VOCs to the atmosphere are both anthropogenic and natural emissions. Major anthropogenic VOCs are emitted from trafficrelated sources such as vehicle exhaust and gasoline evaporation and non-traffic related sources such as solvent use, natural gas leaks and liquefied petroleum gas (LPG), and industrial processes (Saito et al., 2009).

Ground level $\mathrm{O}_{3}$ is considered one of the most important photooxidants (secondary pollutant) that are produced through a series of photochemical reactions. It is a key precursor of $\mathrm{OH}$ radicals which 
control the oxidizing power and chemical composition of the atmosphere (Logan et al., 1981 and Thompson, 1992). The level of $\mathrm{OH}$ in the atmosphere in turn influences the levels of many primary air pollutants such as $\mathrm{CH}_{4}, \mathrm{CO}$ and $\mathrm{SO}_{2}$ (Poulida et al., 1991). In addition, the elevated $\mathrm{O}_{3}$ concentrations have a particular concern due to their deleterious effects on public health as well as damages ecosystems, agricultural crops and materials (Brönnimann et al., 2002 and Wang et al., 2003). Ground level $\mathrm{O}_{3}$ is formed through a series of complex photochemical reactions among its precursors $\left(\mathrm{NO}_{\mathrm{x}}, \mathrm{CO}\right.$ and VOCs) in the presence of sunlight and temperature (Seinfeld and Pandis, 1998; Derwent et al., 2003; Abdul-Wahab et al., 2005; Zhang et al., 2004; Tie et al., 2006; Alvim-Ferraz et al., 2006 and khoder, 2009). Once formed, $\mathrm{O}_{3}$ quickly reacts with $\mathrm{NO}$ regenerating $\mathrm{NO}_{2}$ in the absence of VOCs. The high concentration of VOCs always increases $\mathrm{O}_{3}$ formation, whereas increasing of $\mathrm{NO}_{\mathrm{x}}$ leads to more or less $\mathrm{O}_{3}$, depending on the prevailing ratio between (VOCs) and $\left(\mathrm{NO}_{\mathrm{x}}\right)$ (Seinfeld and Pandis, 1998; Barros, 1999; Guicherit and Roemer, 2000; Sadanga et al., 2003 and Pereira et $a l ., 2005)$. In the presence of VOCs, the oxidation processes of the VOCs play an important role in the oxidation of $\mathrm{NO}$ to $\mathrm{NO}_{2}$ without consumption of $\mathrm{O}_{3}$.

Air pollution in Saudi Arabia is now recognized to be of significant environmental problem due to the presence of intensive anthropogenic activities. Heavy traffic density in the streets of the urban areas leads to an increase in the emission of $\mathrm{O}_{3}$ precursors $\left(\mathrm{NO}_{\mathrm{x}}\right.$ and VOCs), and the problem of pollution had been shifted towards the so called photochemical pollutants. The formation of those pollutants in the atmosphere of the urban areas in Saudi Arabia is facilitated by the local climatic conditions (high temperature, intense solar radiation, clear sky).

The assessment of air quality in urban environment, using the available air quality data will help generate information aiding in planning pollution control strategies to keep the pollutants within safe limits. Air quality data is necessary to understand the trends in depth that will lead to more realistic findings and conclusions. Most of the previous studies about air pollution in Saudi Arabia had been carried out in the Holy City of Makkah, focused on the central area near the Holy Mosque and on the Holy places (Mina, Arafat and Al-Taneem areas) (Al-Jeelani, 2009a and b, Al-Jeelani and Ramadhan, 2004 and 2005; Yacob, 2000; Al-Thumali, 1998; Badwi and Al-Hosary, 1993 and Al-Amri and Abu- 
Alghat, 1992) and inside the tunnels near the Holy Mosque (Al-Jeelani, 1998; Al-Raddadi, 1996 and Al-Sawas, 1995). There is insufficient or lack of information about the air pollution levels in Almadinah Al Menawwarah atmosphere. Therefore, the present study aims to: (1) Evaluate the levels of $\mathrm{NO}, \mathrm{NO}_{2} \mathrm{NO}_{\mathrm{x}}, \mathrm{O}_{3}, \mathrm{SO}_{2}, \mathrm{CO}, \mathrm{CH}_{4}$, and $\mathrm{NMHCs}$ from Ramadan to Hajj season (October, 2005 - January, 2006) in

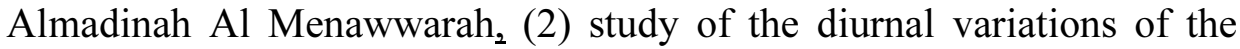
measured gases and factors affecting them, and (3) investigate the relationships between the measured gases.

\section{Materials and Methods}

\section{Sampling Site}

Al Madinah Al Menawwarah is a city in the Hejaz region of western Saudi Arabia. It is the second holiest city in Islam and it has a population of more than $1,300,000$ people. It is located at about $340 \mathrm{~km}$ north of Makkah and $\approx 190 \mathrm{~km}$ from the Red Sea coast at a height of $\approx 600 \mathrm{~m}$ from the mean sea level. The area of Almadinah is $\approx 590 \mathrm{~km}^{2}$, the area occupied by the city's urban area is $\approx 293 \mathrm{~km}^{2}$. The area outside the urban area consists of mountains and valleys and slopes of Seoul and desert land and agricultural activities and parts of the network of highways. The climate of Almadinah is generally dry and characterized by high temperatures ranging from $28-42 \mathrm{C}^{0}$ in the summer and $11-24 \mathrm{C}^{0}$ in the winter. The relative humidity is low throughout the year except for rainfall periods and averaging $\approx 22 \%$. The average annual rainfall is $\approx 3.94 \mathrm{~mm}$ and the city is exposed to northwesterly and westerly winds in general. The wind speed ranges between $9.26-14.8 \mathrm{~km} / \mathrm{h}$.

\section{Air Sampling}

Air quality monitoring mobile station (Environment SA, France) was used to conduct the measurements of pollutants including: $\mathrm{NO}, \mathrm{NO}_{2}$, $\mathrm{NO}_{\mathrm{x}}, \mathrm{O}_{3}, \mathrm{CO}, \mathrm{SO}_{2}, \mathrm{NMHCs}$ and $\mathrm{CH}_{4}$. Calibration was done daily and no data was recorded during that period. Average hourly measurements were taken in the period from Ramadan to Hajj season (October, 2005 January, 2006). To study the effect of traffic density on the air quality of the study area, the data have been classified into seven periods: October $8^{\text {th }}-$ November $2^{\text {nd }}, 2005(A), 3^{\text {rd }}-12^{\text {th }}$ November, 2005 (B), November $13^{\text {th }}-26^{\text {th }}, 2005-$ November, 2005 (C), $20^{\text {th }}-31^{\text {st }}$ December, 2005 (D), $1^{\text {st }}$ 
- $8^{\text {th }}$ January, 2006 (E), $9^{\text {th }}-14^{\text {th }}$ January, $2006(\mathrm{~F})$, and $15^{\text {th }}-30^{\text {th }}$ January, 2006.

\section{Statistical Analysis}

The correlation coefficient $(r)$ and the correlation significant $t$-test were determined using the alternative method of calculation (Gregory, 1963).

\section{Results and Discussion}

\section{Air Quality at the Study Area during the Period of Study}

Presented in Fig. 1 the daily average concentrations ranged from 0.020 to $0.124 \mathrm{ppm}$ with an average value of $0.055 \mathrm{ppm}$ for $\mathrm{NO}$ and from 0.018 to $0.070 \mathrm{ppm}$ with an average value of $0.040 \mathrm{ppm}$ for $\mathrm{NO}_{2}$. The daily average concentrations of $\mathrm{NO}_{\mathrm{x}}\left(\mathrm{NO}+\mathrm{NO}_{2}\right)$ ranged from 0.040 to $0.187 \mathrm{ppm}$ with a mean value of $0.095 \mathrm{ppm}$. In the current study the average $\mathrm{NO}_{2}$ concentration $(0.055 \mathrm{ppm})$ was lower than those found in the city centre (Ramsis square) of Cairo, Egypt (0.117, 0.137, 0.100 and $0.089 \mathrm{ppm}$ in the autumn, winter, spring and summer seasons, respectively, (Khoder, 2004) and in Dokki, Giza, Egypt (0.098 ppm) in the winter and $0.070 \mathrm{ppm}$ in the summer season, Khoder, 2002). On the other hand, the average $\mathrm{NO}_{2}$ concentration in the present study was higher than those found in Beijing $(0.038 \mathrm{ppm})$, (Wang et al., 2008) and in Al-Taneem area in the Holy Makkah city, Saudi Arabia $(0.018 \mathrm{ppm}),($ Al-Jeelani, 2009a), in Germany (0.018 ppm), the Netherlands (0.020 ppm), Rotterdam (0.021 ppm) and Sweden (0.015 ppm), (Lewne et al., 2004), in Kolkata, India (0.017 ppm), (Gupta et al., 2008) and in the city of Eskisehir, Turkey $(0.016 \mathrm{ppm})$ in winter and $(0.008 \mathrm{ppm})$ in summer, (Özden et al., 2008).

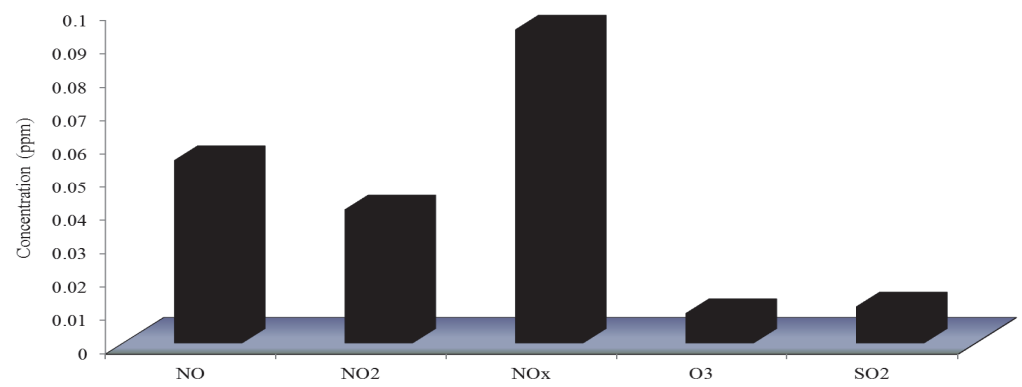

Fig. 1. The daily average concentrations of $\mathrm{NO}, \mathrm{NO}_{2}, \mathrm{NO}_{\mathrm{x}}, \mathrm{O}_{3}$ and $\mathrm{SO}_{2}$ during the period of study. 
The average concentrations of $\mathrm{NO}_{\mathrm{x}}(0.095 \mathrm{ppm})$ in the present study was lower than that found in holy Makkah city, Saudi Arabia, during Hajj season 1425 H (0.15 ppm), (Al-Jeelani, 2009b) and much higher than those found in Al-Taneem area in the Holy Makkah city, Saudi Arabia (0.033 ppm), (Al-Jeelani, 2009a) and in Mena area during Hajj season $1424 \mathrm{H}$ (0.078 ppm), (Al-Jeelani, 2009).

The daily average concentrations of $\mathrm{SO}_{2}(0.011 \mathrm{ppm})$ (Fig. 1) was nearly similar to those found in Al-Taneem area in the Holy Makkah city, Saudi Arabia (0.010 ppm), (Al-Jeelani, 2009a) and in Ankara, Turkey (0.011 ppm), (DRSCH, 2006).On the other hand, the average concentrations of $\mathrm{SO}_{2}$ in the present study was lower than those found in Dokki, Giza, Egypt $(0.048 \mathrm{ppm})$ in winter and $(0.032 \mathrm{ppm})$ in summer, (Khoder, 2002), in Dhaka, Bangladesh (0.045 ppm) (Gurjar et al., 2008) and in China (0.114 ppm), (Lei et al., 1997) and relatively lower than those found in Mexico City, Mexico (0.018 ppm), (Gurjar et al., 2008) and in Eskisehir, Turkey (0.018 ppm) $($ Özden et al., 2008) in Izmir, Turkey (0.015 ppm), (DRSCH, 2006), in the Holy Makkah city, Saudi Arabia during Hajj season 1425 H (0.016 ppm) (Al-Jeelani, 2009b) and in Mena area during Hajj season 1424 H (0.015 ppm), (Al-Jeelani, 2009). On the other hand, the average concentration of $\mathrm{SO}_{2}$ in the current study was much higher than those found in Beirut, Lebanon $(0.003 \mathrm{ppm})$, (Afif et al., 2008), in Roma, Italy (0.006 ppm) (Avino and Manigrasso, 2008), in Pamplona, Spain (0.003 ppm) (Zabalza et al., 2007) in Thurroch, UK (0.002 ppm), (UK Air Quality Archive, 2008) and relatively higher than that found in New York, USA (0.009 ppm) (USEPA, 2008) and in Beijing (0.009 ppm) (Wang et al., 2008)

The daily average concentrations of $\mathrm{O}_{3}(0.009 \mathrm{ppm})$ in this study were much lower than those found in Giza (Haram), Egypt, during the winter $(0.030 \mathrm{ppm})$, spring $(0.048 \mathrm{ppm})$, summer $(0,064 \mathrm{ppm})$ and autumn $(0.043 \mathrm{ppm})$, (Khoder, 2009), and in the city centre of Cairo, Egypt, $(0.040,0.058,0.079,0.051 \mathrm{ppm})$ during the corresponding seasons, respectively (Khoder, 2004), in Eskisehir, Turkey (0.019 and $0.027 \mathrm{ppm})$ during the winter $(0.019 \mathrm{ppm})$ and in summer $(0.027 \mathrm{ppm})$, (Özden et al., 2008) and in Al-Taneem area in the Holy Makkah city, Saudi Arabia (0.021 ppm), (Al-Jeelani, 2009a). In contrast $\mathrm{SO}_{2}$ average concentration was higher than that found in the Holy Makkah city, Saudi Arabia during Hajj season 1425 H (0.004 ppm), (Al-Jeelani, 2009b). 
The daily average concentrations of $\mathrm{CO}, \mathrm{CH}_{4}$ and $\mathrm{NMHCs}$ during the period of study are graphically presented in Fig. 2 . The daily average concentrations of $\mathrm{CO}$ ranged from (1.18 to $4.82 \mathrm{ppm}$ ) with an average of $(2.82 \mathrm{ppm})$. This average concentration was higher than those found in Beijing (1.97 ppm) (Wang et al., 2008) in Al-Taneem area in the Holy Makkah city, Saudi Arabia (1.39 ppm) (Al-Jeelani, 2009a), and nearly similar to that found in Mena area during Hajj season 1424 H (2.45 ppm, Al-Jeelani, 2009). On the other hand, the daily average concentration of $\mathrm{CO}$ in this study was lower than that found in Holy Makkah city, Saudi Arabia during Hajj season 1425 H (11.30 ppm, Al-Jeelani, 2009b).

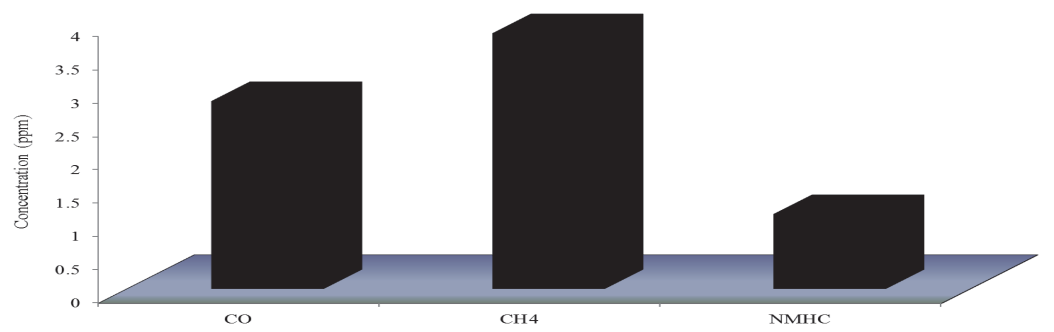

Fig. 2. The daily average concentrations of $\mathrm{CO}, \mathrm{CH}_{4}$ and NMHCs during the period of study.

The daily average concentrations of $\mathrm{CH}_{4}$ and NMHCs in the present study were 3.83 and $1.12 \mathrm{ppm}$, respectively (Figu 2). The daily average concentrations of $\mathrm{CH}_{4}(3.83 \mathrm{ppm})$ and $\mathrm{NMHC}(1.12 \mathrm{ppm})$ were higher than those found in Al-Taneem area in the Holy Makkah city, Saudi Arabia $(2.15 \mathrm{ppm})$ for $\mathrm{CH}_{4}$ and $(0.39 \mathrm{ppm})$ for NMHCs (Al-Jeelani, 2009a). In addition, the daily average concentrations of NMHCs in this study was higher than those found in Nagoya, Japan $(0.028 \mathrm{ppm})$ (Saito et al., 2009), London, UK (0.030 ppm) (Derwent et al., 2000), Lille, France (0.022 ppm), (Borbon et al., 2002), Seoul, Korea (0.052 ppm), ( $\mathrm{Na}$ and Kim, 2001) and Dallas, USA (0.041 ppm), (Qin et al., 2007).

Mobile emission sources are predominantly characterized by high NOx and $\mathrm{CO}$ concentrations, and point emission sources by high $\mathrm{SO}_{2}$ and NOx. So, the mobile sources have relatively low $\mathrm{SO}_{2} / \mathrm{NO}_{\mathrm{x}}$ ratios (Aneja et al., 2001). In the current study, the $\mathrm{SO}_{2} / \mathrm{NO}_{\mathrm{x}}$ and $\mathrm{SO}_{2} / \mathrm{NO}_{2}$ concentration ratios were 0.12 and 0.28 during the period of study, respectively, suggesting that the mobile emissions are the predominant source within the study area. The $\mathrm{SO}_{2} / \mathrm{NO}_{2}$ concentration ratio at the 
study area during the period of study was lower than those found in Kolkata, India (ranged from 0.38 - 0.41) (Gupta et al., 2008).

\section{Diurnal Variations of $\mathrm{NO}, \mathrm{NO}_{2}, \mathrm{NO}_{x}, \mathrm{O}_{3}, \mathrm{NMHC}, \mathrm{CO}, \mathrm{CH}_{4}$ and $\mathrm{SO}_{2}$ Concentrations}

The hourly variations of air pollutants provide valuable information on their sources, transport and chemical formation/destruction. Figure 3 shows the diurnal variations in $\mathrm{NO}, \mathrm{NO}_{2}, \mathrm{NO}_{\mathrm{x}}$ and NMHCs concentrations during the period of study. The hourly concentrations of NO increased from 06.00 to $08.00 \mathrm{~h}$, and then decreased in mid-day time. After that time, the concentration increased again to give a second peak in the late evening. The morning peak $(0.062 \mathrm{ppm}$ at $08.00 \mathrm{~h})$ was lower in magnitude than that of the late evening one $(0.089 \mathrm{ppm}$ at $21.00 \mathrm{~h})$. The trend of $\mathrm{NO}_{2}$ hourly concentrations was similar to that of $\mathrm{NO}$ concentrations, with the morning peak was achieved at $08.00 \mathrm{~h}(0.043$ $\mathrm{ppm})$ and late evening peak at $20.00-21.00 \mathrm{~h}(0.052 \mathrm{ppm})$. The diurnal variations of $\mathrm{NO}_{\mathrm{x}}$ concentrations was also similar to the trend of $\mathrm{NO}$ and $\mathrm{NO}_{2}$, with double peaks, in the morning at $08.00 \mathrm{~h}(0.110 \mathrm{ppm})$ and late evening at $21.00 \mathrm{~h}(0.141 \mathrm{ppm})$. These double peak patterns of $\mathrm{NO}, \mathrm{NO}_{2}$ and $\mathrm{NO}_{\mathrm{x}}$ may be the typical signature of urban influence boundary layer processes, surface wind pattern, emissions, transportation/work cycle and chemical processes. During the morning time, the increase in the emission rate from traffic, accompanied with a poorer dispersive conditions and lower photochemical reaction lead to accumulate the concentrations of air pollutants. Latha and Badarinath (2003) reported that high levels of NOx during the morning and late evening can be attributed to combinations of anthropogenic emissions, boundary layer processes, chemistry as well as local sources and wind patterns. In the present study, the low concentrations of $\mathrm{NO}$ and $\mathrm{NO}_{2}$ during the mid-day time may be due to the high dispersion and high dilution conditions, under the effect of high temperature, which increases the thermal turbulence currents. Moreover, the high temperature and solar radiation intensity during the mid-day time lead to increase the photochemical reactions and consequently increasing the chemical loss of those pollutants. 


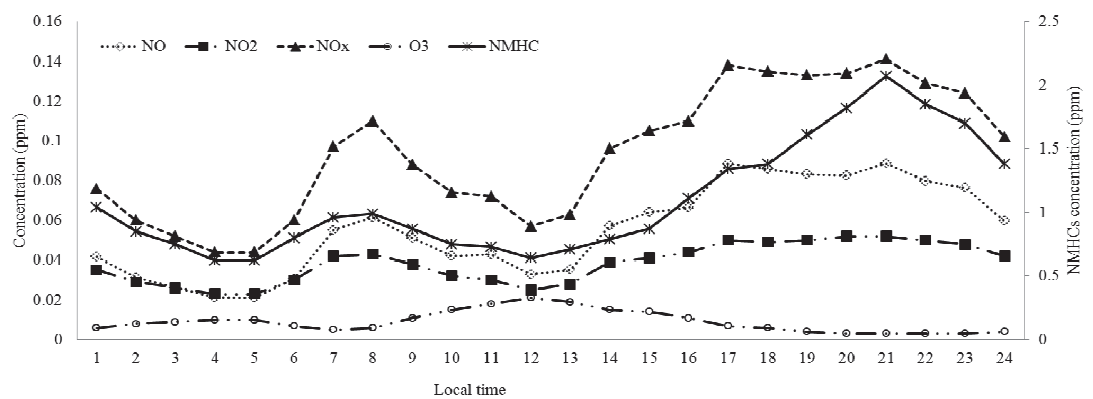

Fig. 3. Diurnal variations in $\mathrm{NO}, \mathrm{NO}_{2}, \mathrm{NO}_{\mathrm{x}}$ and $\mathrm{NMHCs}$ concentrations during the period of study.

This leads to decrease the $\mathrm{NO}_{\mathrm{x}}$ concentrations in the mid-day time. This corresponds with Rao et al. (2002a \& b) who attributed that the variations in $\mathrm{NO}_{\mathrm{x}}$ to variations in boundary layer mixing processes, chemistry, anthropogenic emissions, and local surface wind patterns. During the late evening and nighttime, the boundary layer descends and remains low until early morning, thereby resisting the mixing of anthropogenic emissions with the upper layer. Hence, pollutants get trapped in a shallow surface layer resulting in raising levels of $\mathrm{NO}, \mathrm{NO}_{2}$ and $\mathrm{NO}_{\mathrm{x}}$ in the current study (Fig. 3).

It can be noticed that, the trend of NMHCs concentrations was similar to those of $\mathrm{NO}, \mathrm{NO}_{2}$ and $\mathrm{NO}_{\mathrm{x}}$ concentrations (Fig. 3), whereas it was inverse with $\mathrm{O}_{3}$ concentrations. The morning peak $(0.99 \mathrm{ppm}$ at $08.00 \mathrm{~h})$ was lower in magnitude than that of the late evening peak (2.07 ppm at $21.00 \mathrm{~h}$ ). This two-peak pattern had also been observed in many other sites, such as Changchun, China (Liu et al., 2000); Taichung, Taiwan (Yang et al., 2005); and Bilbao, Spain (Durana et al., 2006). The pattern suggested that the dominant effect in the early morning and late evening was of traffic density, that resulted in the increase of exhaust from vehicles. The mid-day time minimum concentrations of NMHCs may be attributed to dilution processes induced by increasing in the mixing depth, reduced emissions and its depletion due to photochemical reactions. The major sink of hydrocarbons is the $\mathrm{OH}$ radical which reaches its peak at noon due to the high solar radiation and temperature.

The diurnal variations of $\mathrm{O}_{3}$ concentrations during the period of study are graphically presented in Figure $3 . \mathrm{O}_{3}$ showed a uni-peak pattern with the highest levels during the daytime and the lowest levels in the nighttime, with a uni-modal $\mathrm{O}_{3}$ peak during the daytime. This is 
attributed to higher temperature, and solar radiation intensity during the daytime, which are the favorable conditions to power the photochemical reactions. Minimum concentrations of $\mathrm{O}_{3}$ appear in the nighttime and early morning hours (near sunrise) due to the combined effects of chemical loss by $\mathrm{NO}$ and $\mathrm{NO}_{2}$ species and suppressed boundary layer mixing processes. During the morning, concentrations of $\mathrm{NO}_{\mathrm{x}}$ are high, which leads to destruction of $\mathrm{O}_{3}$ (Badarinath et al., 2007). In the present study, the $\mathrm{O}_{3}$ concentration increased after the sun rises and reached its maximum levels at $12.00 \mathrm{~h}$, with a mean value of $0.021 \mathrm{ppm}$. After that time, $\mathrm{O}_{3}$ concentration decreased again. Variation in $\mathrm{O}_{3}$ concentration had a tendency to follow the solar radiation intensity, resulting in higher $\mathrm{O}_{3}$ levels during the daylight periods. This higher level in $\mathrm{O}_{3}$ concentration during the daylight periods is attributed to the photochemical processes of $\mathrm{O}_{3}$ formation. On the other hand, as the sun goes down in the evening and nighttime, the photochemical processing of $\mathrm{O}_{3}$ is halted due to the absence of the photochemical reactions, and the $\mathrm{O}_{3}$ that remains in the atmosphere is then consumed by deposition and/or reaction with $\mathrm{NO}$ which acts as a sink for $\mathrm{O}_{3}$.

Diurnal variations of $\mathrm{CO}, \mathrm{SO}_{2}$ and $\mathrm{CH}_{4}$ concentrations during the period of study are graphically presented in Fig. 4. They showed double peaks patterns. The hourly concentrations of $\mathrm{CO}$ increased from 06.00 to $08.00 \mathrm{~h}$, and then decreased in the mid-day time. After that time, the concentration increased again to give a second peak in the late evening. The morning peak $(2.85 \mathrm{ppm}$ at $08.00 \mathrm{~h})$ was lower in magnitude than that of the late evening peak $(4.91 \mathrm{ppm}$ at $21.00 \mathrm{~h})$. These double peak patterns may be the typical signature of urban influence. The diurnal cycle of $\mathrm{CO}$ is related to the transportation/work cycle, metrological conditions and photochemical reactions. The boundary layer in the late evening descends and remains low until early morning, thereby resisting the mixing of anthropogenic emissions with the upper layer. This will lead to increase the accumulation of $\mathrm{CO}$ in a shallow surface layer and consequently, the level of CO in that time is increased. During morning and late evening, the highest levels of $\mathrm{CO}$ may be attributed to combinations of anthropogenic emissions, boundary layer processes, chemistry as well as local sources and wind patterns (Latha and Badarinath, 2003).During nighttime, formaldehyde (HCHO) accumulates while during the morning its chemical reaction and photo dissociation results in the production of $\mathrm{CO}$ (Badarinath et al., 2007). In the present 
study, the observed diurnal cycle of $\mathrm{CO}$ was inversed of that of $\mathrm{O}_{3}$ (Fig. 1). The reaction of $\mathrm{OH}$ is the primary mechanism for the removal of $\mathrm{CO}$ from the atmosphere. Major chemical loss of $\mathrm{CO}$ is by reaction with $\mathrm{OH}$ radical during daytime, producing ozone (Badarinath et al., 2007). In the present study, the comparison of the diurnal cycles of $\mathrm{O}_{3}$ and $\mathrm{CO}$, indicated that the depletion of $\mathrm{O}_{3}$ and the enhancement of $\mathrm{CO}$ during the non-photochemistry hours (morning and late evening) came from the $\mathrm{O}_{3}$ titration when mixed with urban emissions and simultaneously the anthropogenic release of $\mathrm{CO}$.

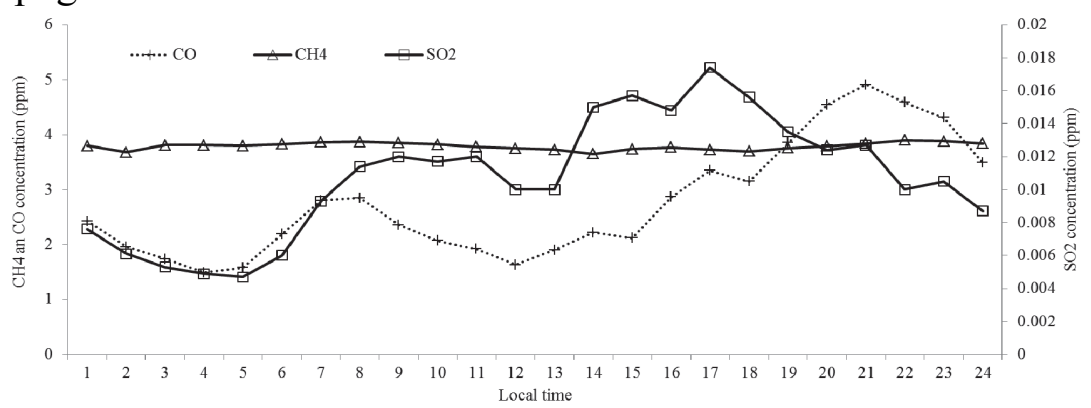

Fig. 4. Diurnal variations of $\mathrm{CO}, \mathrm{SO}_{2}$ and $\mathrm{CH}_{4}$ concentrations during the period of study.

The hourly concentrations of $\mathrm{SO}_{2}$ generally increased from 06.00 to $11.00 \mathrm{~h}$, and decreased in the mid-day time. After that time, the concentration increased again to give the main peak in the evening (5 $\mathrm{pm})$. The concentrations of $\mathrm{SO}_{2}$ in the early morning, late evening and night exceed their daylight concentrations due to the presence of temperature inversions during these periods and the absence of photochemical reactions. The relatively lower daytime concentrations of $\mathrm{SO}_{2}$ would be attributed to the difference in emissions, relatively higher oxidation of $\mathrm{SO}_{2}$ to sulfate, under the effect of solar radiation,(Harrison and Perry, 1986). Khoder's (2002) results show that the oxidation processes and conversion of $\mathrm{SO}_{2}$ to sulfate depend on the photochemical oxidation and that the sulfur conversion ratio increases with increasing ozone concentration. In the present study, there was no diurnal variation in hourly $\mathrm{CH}_{4}$ concentrations during the periods of study. The hourly concentrations of $\mathrm{CH}_{4}$ ranged from $3.65 \mathrm{ppm}$ at $14.00 \mathrm{~h}$ to $3.91 \mathrm{ppm}$ at $22.00 \mathrm{~h}$.

The results of daily (24-h) minimum, maximum and average concentrations of $\mathrm{NO}_{2}, \mathrm{O}_{3}, \mathrm{SO}_{2}$ and $\mathrm{CO}$ were compared with the available air quality standards in different countries (Table 1). The 
concentrations of these pollutants did not exceed the available standards. Although, the studied area does not suffer from $\mathrm{NO}_{2}, \mathrm{O}_{3}, \mathrm{SO}_{2}$ and $\mathrm{CO}$ pollution and no health risk, comprehensive, long-term air quality management programs are needed in order to keep air quality in a good condition.

Table 1. Air quality standards in different countries (Al-Jeelani, 2009a).

\begin{tabular}{|c|c|c|c|c|}
\hline Standards (ppm) & $\mathrm{CO}$ & $\mathrm{NO}_{2}$ & $\mathrm{O}_{3}$ & $\mathrm{SO}_{2}$ \\
\hline NAAQSs (USA) 1-h average & 35 & & 0.12 & \\
\hline NAAQSs (USA) 24-h average & & & & 0.14 \\
\hline NAAQSs (Canada) Desirable 1-h average & 13.1 & & 0.051 & 0.172 \\
\hline NAAQSs (Canada) Desirable 24-h average & & & 0.015 & 0.057 \\
\hline NAAQSs (Canada) Acceptable 1-h average & 30.6 & 0.213 & 0.082 & 0.334 \\
\hline NAAQSs (Canada) Acceptable 24-h average & & 0.106 & & 0.115 \\
\hline WHO 1-h average & 26 & & $0.05-0.10$ & 0.13 \\
\hline WHO 24-h average & & & & $0.038-0.058$ \\
\hline Alberta Guidelines 1-h average & 13 & 0.21 & 0.082 & 0.17 \\
\hline Alberta Guidelines 24-h average & & 0.11 & 0.025 & 0.06 \\
\hline NAAQSs (Korea) 1-h average & 25 & 0.15 & 0.1 & 0.15 \\
\hline NAAQSs (Korea) 24-h average & & 0.8 & 0.06 & 0.05 \\
\hline PME (MEPA) 1-h average & 35 & 0.35 & 0.15 & 0.28 \\
\hline PME (MEPA) 24-h average & & & & 0.14 \\
\hline
\end{tabular}

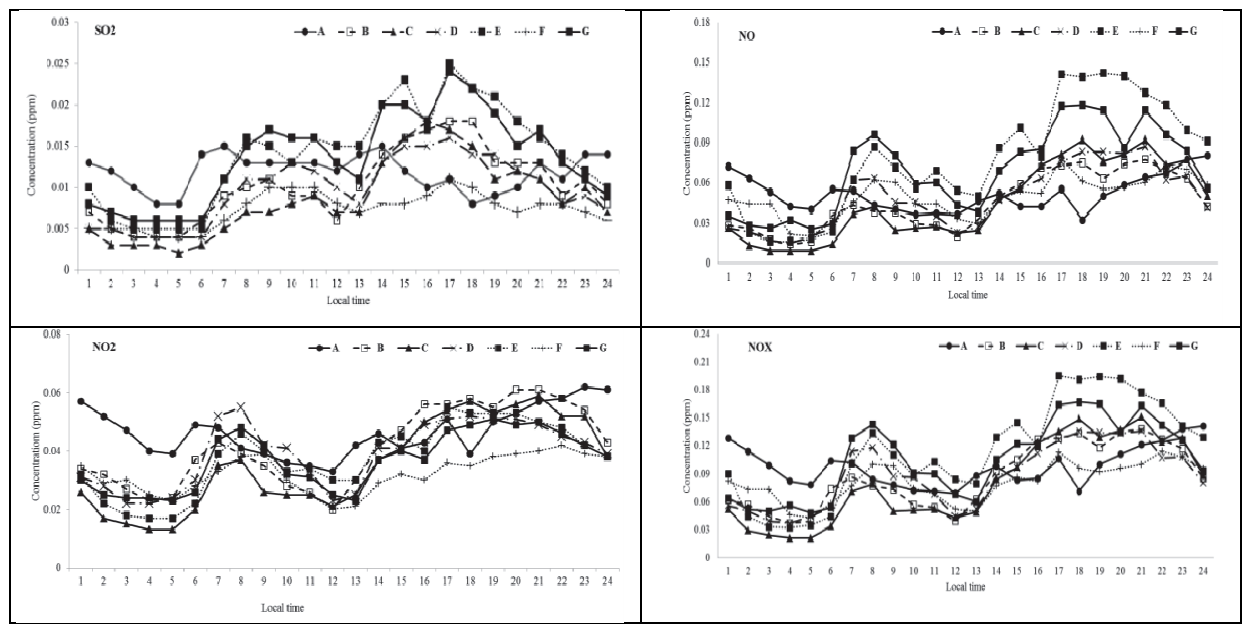




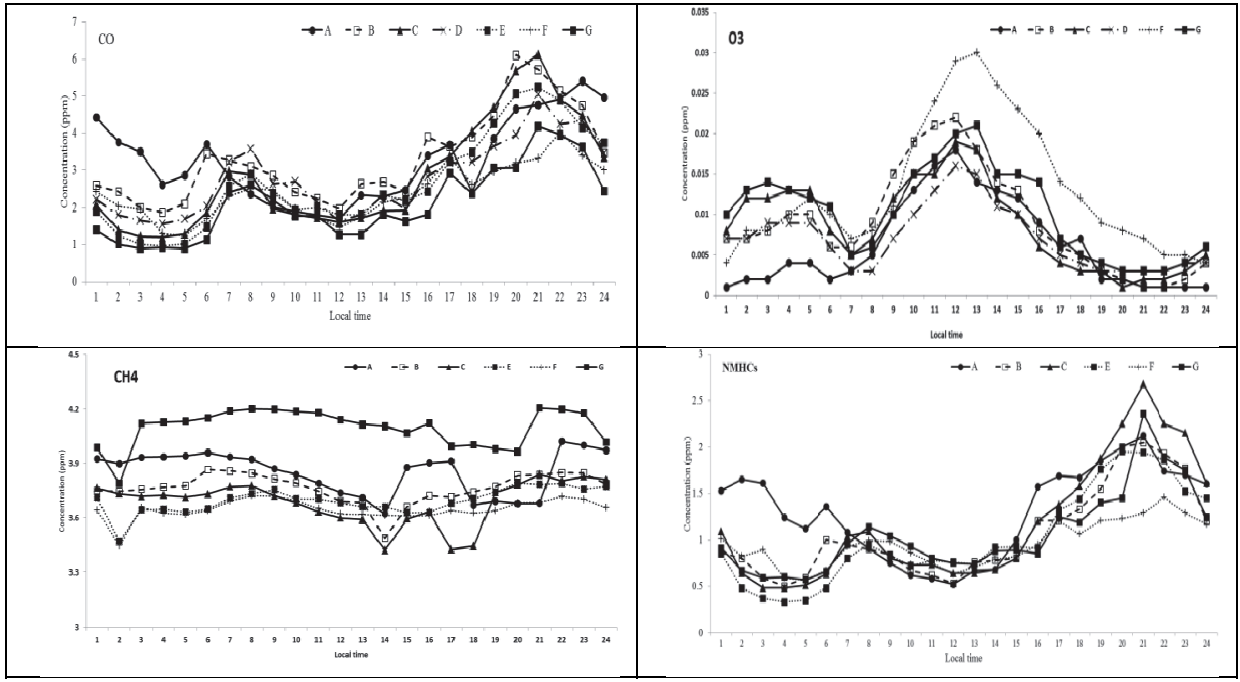

Fig. 5. Comparison of diurnal variations of $\mathrm{NO}, \mathrm{NO}_{2}, \mathrm{NOx}, \mathrm{NMHCs}, \mathrm{O}_{3}, \mathrm{CH} 4, \mathrm{CO}$ and $\mathrm{SO}_{2}$ concentrations during the periods of October 8, 2005 - November 2, 2005 (A), November 3, 2005 - November 12, 2005 (B), November 13, 2005 - November 26, 2005(C), December 20, 2005 - December 31, 2005 (D), January 1, 2006 - January 8, 2006 (E), January 9, 2006-January 14, 2006 (F), and January 15, 2006- January 30, 2006 (G).

\section{Comparison of Diurnal Variations of the Measured Pollutants during Different Time Periods}

The diurnal variations of $\mathrm{NO}, \mathrm{NO}_{2}, \mathrm{NOx}, \mathrm{O}_{3}, \mathrm{NMHCs}, \mathrm{CH}_{4}, \mathrm{CO}$ and $\mathrm{SO}_{2}$ during different periods are graphically presented in Fig. 5. It can be noticed that, a similar behavior trends in hourly concentrations were observed for the different periods of times, with the morning and late evening peaks. The highest hourly concentrations were found in $15^{\text {th }}-30^{\text {th }}$ January 2006, for NO, $8^{\text {th }}$ October $-2^{\text {nd }}$ November 2005 , for $\mathrm{NO}_{2}$, and $1^{\text {st }}$ - $8^{\text {th }}$ January for NOx. In addition, the highest hourly concentrations were found in $8^{\text {th }}$ October $-2^{\text {nd }}$ November 2005 for NMHCs, $8^{\text {th }}$ October $-2^{\text {nd }}$ November 2005 , for $\mathrm{CO}$ and $1^{\text {st }}-8^{\text {th }}, 15^{\text {th }}-30^{\text {th }}$ January for $\mathrm{SO}_{2}$. With regard to the diurnal variations of $\mathrm{O}_{3}$ during different periods of study (Fig. 5), a similar behavior trends in $\mathrm{O}_{3}$ hourly concentrations was observed for all different periods of times, with a uni-modal peak during the daytime. The highest hourly concentrations of $\mathrm{O}_{3}$ were found in $9^{\text {th }}$ $14^{\text {th }}$ January 2006. For $\mathrm{CH}_{4}$, did not show diurnal variation during the different periods of study (Fig. 5), with the highest concentrations in $15^{\text {th }}$ $30^{\text {th }}$ January 2006 , followed by $8^{\text {th }}$ October $-2^{\text {nd }}$ November 2005 and $3^{\text {rd }}$ $-12^{\text {th }}$ November 2005. 
The daily average concentrations were $0.052,0.045,0.044,0.049$, $0.078,0.050$ and $0.069 \mathrm{ppm}$ for NO, 0.047, 0.041, 0.035, 0.039, 0.038, 0.032 and $0.037 \mathrm{ppm}$ for $\mathrm{NO}_{2}, 0.098,0.086,0.079,0.087,0.115,0.081$ and $0.105 \mathrm{ppm}$ for NOx, 3.28, 3.30, 2.74, 2.79, 2.67, 2.41 and $2.10 \mathrm{ppm}$ for $\mathrm{CO}$ and $0.012,0.010,0.009,0.010,0.014,0.007$ and $0.014 \mathrm{ppm}$ for $\mathrm{SO}_{2}$ during the periods of October 8 - November 2, 2005, November 3 November 12, 2005, November 13 - November 26, 2005, December 20 December 31 , 2005, January 1 - January 8, 2006, January 9 - January 14, 2006 and January 15 - January 30, 2006, respectively. In addition, the daily average concentrations of $\mathrm{O}_{3}$ were $0.006 \mathrm{ppm}$ in October 8 November 2, 2005, $0.009 \mathrm{ppm}$ in November 3 - November 12, 2005, $0.009 \mathrm{ppm}$ in November 13 - November 26, 2005, $0.007 \mathrm{ppm}$ in December 20 - December 31, 2005, 0.013 ppm in January 9 - January 14, 2006 and $0.011 \mathrm{ppm}$ in January 15 - January 30, 2006. With regard to $\mathrm{CH}_{4}$ and $\mathrm{NMHC}$, the daily average concentrations were $3.89,3.76$, $3.68,3.69,3.65$ and $4.100 \mathrm{ppm}$ for $\mathrm{CH}_{4}$ and $1.30,1.06,1.17,1.02,0.95$ and $1.06 \mathrm{ppm}$ for NMHCs during the corresponding periods respectively. Generally, the highest concentration levels of the measured pollutants in the study area were observed during Ramadan (8 october-2 November 2005) and Hajj (1-8 and 15-30 January 2006) days. This may be attributed to the high emission of pollutants from heavy traffic during Ramadan and Hajj days.

\section{Correlation within the Measured Air Pollutants During the Period of Study}

Correlation coefficients within the measurement of air pollutants are shown in Table 2. Statistically significant correlation coefficients $(\mathrm{P}<$ $0.05)$ are highlighted in bold. Significant positive correlation coefficients were found between $\mathrm{NO}, \mathrm{NO}_{2}, \mathrm{NOx}, \mathrm{NMHCs}$ and $\mathrm{CO} . \mathrm{SO}_{2}$ concentrations were positively correlated with $\mathrm{NO}, \mathrm{NO}_{2}, \mathrm{NOx}, \mathrm{NMHCs}$ and $\mathrm{CH}_{4}$. These results indicated that these pollutants originate from similar or co-located sources. Significant negative correlation coefficients were found between $\mathrm{O}_{3}$ concentrations and $\mathrm{NO}_{2}$, since $\mathrm{NO}_{2}$ is an important precursor for $\mathrm{O}_{3}$, which is constantly consumed by the photochemical reactions and produced lots of $\mathrm{O}_{3}$. Negative correlation coefficients were found between $\mathrm{O}_{3}$ concentration and $\mathrm{NO}, \mathrm{NO}_{2}$ as well as NOx (Abdul-Wahab et al., 2005; Pudasainee et al., 2006 and khoder, 2009), these results confirmed the finding of the present study. 
Table 2. Correlation coefficients among different pollutants during the period of study.

\begin{tabular}{|l|l|l|l|l|l|l|l|l|}
\hline & $\mathrm{NO}$ & $\mathrm{NO}_{2}$ & $\mathrm{NO}_{\mathrm{x}}$ & $\mathrm{SO}_{2}$ & $\mathrm{O}_{3}$ & $\mathrm{CH}_{4}$ & $\mathrm{NMHCs}$ & $\mathrm{CO}$ \\
\hline $\mathrm{NO}$ & 1.00 & $\mathbf{0 . 5 5}$ & $\mathbf{0 . 9 6}$ & $\mathbf{0 . 7 7}$ & -0.02 & $\mathbf{0 . 2 9}$ & $\mathbf{0 . 3 9}$ & $\mathbf{0 . 2 5}$ \\
$\mathrm{NO}_{2}$ & & 1.00 & $\mathbf{0 . 7 6}$ & $\mathbf{0 . 6 2}$ & $\mathbf{- 0 . 3 5}$ & 0.20 & $\mathbf{0 . 5 9}$ & $\mathbf{0 . 6 4}$ \\
\hline $\mathrm{NO}_{\mathrm{x}}$ & & & 1.00 & $\mathbf{0 . 8 1}$ & -0.14 & $\mathbf{0 . 2 9}$ & $\mathbf{0 . 5 0}$ & $\mathbf{0 . 4 1}$ \\
\hline $\mathrm{SO}_{2}$ & & & & 1.00 & -0.02 & $\mathbf{0 . 4 0}$ & $\mathbf{0 . 2 2}$ & 0.04 \\
\hline $\mathrm{O}_{3}$ & & & & & 1.00 & $\mathbf{0 . 4 1}$ & $\mathbf{- 0 . 5 8}$ & $\mathbf{- 0 . 4 3}$ \\
\hline $\mathrm{CH}_{4}$ & & & & & & 1.00 & 0.16 & -0.11 \\
\hline $\mathrm{NMHCs}$ & & & & & & 1.00 & $\mathbf{0 . 7 6}$ \\
\hline $\mathrm{CO}$ & & & & & & & & 1.00 \\
\hline
\end{tabular}

$\mathrm{O}_{3}$ concentrations in the present study were negatively correlated with $\mathrm{CO}$ and $\mathrm{NMHCs}$, indicating that the reaction with $\mathrm{OH}$ is the primary mechanism for the removal of these pollutants from the atmosphere. Major chemical loss of $\mathrm{CO}$ in the atmosphere is by reaction with $\mathrm{OH}$ radical during daytime, producing ozone (Badarinath et al., 2007).

\section{Conclusion}

The $\mathrm{SO}_{2} / \mathrm{NOx}$ and $\mathrm{SO}_{2} / \mathrm{NO}_{2}$ concentration ratios suggested that the mobile emissions were the predominant source within the study area. The diurnal variations in $\mathrm{NO}, \mathrm{NO}_{2}, \mathrm{NOx}, \mathrm{SO}_{2}, \mathrm{CO}, \mathrm{NMHCs}$ concentrations had similar trend patterns and inverse of that of $\mathrm{O}_{3}$. The relatively higher traffic density during Ramadan and Hajj seasons lead to increase in the traffic emission, and consequently the concentrations of measured pollutants were increased. The significant positive correlation coefficients between $\mathrm{NO}, \mathrm{NO}_{2}, \mathrm{NOx}, \mathrm{NMHCs}$ and $\mathrm{CO}$, and also between $\mathrm{SO}_{2}$ and $\mathrm{NO}, \mathrm{NO}_{2}, \mathrm{NOx}, \mathrm{NMHCs}$ and $\mathrm{CH}_{4}$ indicating that these pollutants originate from similar or co-located sources. The concentrations of $\mathrm{O}_{3}$ were negatively correlated with $\mathrm{NO}_{2}, \mathrm{CO}$ and NMHCs. The level of 1-h and daily (24-h) average concentrations of $\mathrm{NO}_{2}, \mathrm{O}_{3}, \mathrm{SO}_{2}$ and $\mathrm{CO}$ did not exceed the national and international available air quality standards. It is recommended a comprehensive and long-term air quality management programmes are needed to ensure that tolerable levels of pollution are not exceeded and that the population exposure is reduced to acceptable levels. 


\section{References}

Abdul-Wahab, S.A., Bakheit, C.S. and Al-Alawi, S.M. (2005) Principal component and multiple regression analysis in modeling of ground-level ozone and factors affecting its concentrations. Environmental Modelling and Software, 20: 1263-1271.

Afif, C., Chélala, C., Borbon, A., Abboud, M., Adjizian-Gérard, J., Farah, W., Jambert, C., Zaarour, R., Saliba, N.B., Perros, P. E. and Rizk, T. (2008) $\mathrm{SO}_{2}$ in Beirut: air quality implication and effects of local emissions and long-range transport. Air Qual. Atmos. Health, 1: 167-178.

Al-Amri, A.M. and Abu-Alghat, S. (1992) Study of the air pollution in Makkah City and the Holy places. Third report submitted to Hajj research center, Aum-Alqura University (Arabic text).

Ali, M. and Athar, M. (2008) Air pollution due to traffic, air quality monitoring along three sections of National Highway N-5, Pakistan. Environ. Monit. Assess., 136: 219-226.

Al-Jeelani, H.A. (2009a) Air quality assessment at Al-Taneem area in the Holy Makkah City, Saudi Arabia. Environ. Monit. Assess. 156: 211-222.

Al-Jeelani, H.A. (1998) Effects of traffic on air pollutants concentration inside Souk Alsagheer Tunnel during the month of Ramadhan. Final report submitted to Hajj research center, Aum-Alqura University.

Al-Jeelani, H.A. and Ramadhan, M.H. (2004).Assessment of air quality in Mina and Makkah City during Hajj season. First year report submitted to the Institute of Research and Consultations, King Abdulaziz University (Arabic text).

Al-Jeelani, H.A. (2009) Assessment of air quality in Mena valley during Hajj season 1424H. Journal for Environmental Sciences, Cairo University. 7(1):2009

Al-Jeelani, H.A. (2009b) Evaluation of Air Quality in the Holy Makkah during Hajj Season 1425 H. Journal of Applied Sciences Research, 5(1): 115-121.

Al-Raddadi, A.S. (1996) Study the air quality inside the Souk Alsagheer Tunnel. First report submitted to Hajj Research Center, Aum Alqura University.

Al-Sawas, A. (1995) Air quality of inside King Fahad tunnel during the month of Ramadhan. Final report submitted to Hajj Research Center Aum-Alqura University (Arabic text).

Al-Thumali, Y.A. (1998) Air pollution study of Mina and Arafat Areas during Hajj season 1996 with concentration on suspended particulates and some gases. Master thesis, Department of Environmental Sciences, King Abdulaziz University.

Alvim-Ferraz, M.C.M., Sousa, S.I.V., Pereira, M.C. and Martins, F.G. (2006) Contribution of anthropogenic pollutants to the increase of tropospheric ozone levels in the Oporto Metropolitan Area, Portugal since the 19th century. Environmental Pollution, 140: 516524.

Aneja, V.P., Roelle, P.A., Murray, G.C., Southerland, J., Erisman, J.W., Fowler, D., Asman, W.A.H. and Patni, N. (2001) Atmospheric nitrogen compounds II: emissions, transport, transformation, deposition and assessment. Atmospheric Environment, 35: 1903-1911.

AQEG (2004) Nitrogen Dioxide in the United Kingdom. Report of the UK Air Quality Expert Group. AQEG, 2004.Prepared for the Department of the Environment Food and Rural Affairs, the Scottish Executive, the Welsh Assembly and the Department of the Environment in Northern Ireland. Defra publications, London, March 2004, available at www.defra.gov.UK/environment/airquality/aqeg.

Avino, P. and Manigrasso, M. (2008) Ten-year measurements of gaseous pollutants in urban air by an open-path analyzer. Atmos. Environ., 42: 4138-4148.

Badarinath, K.V.S., Madhavi Latha, K.,, Kiran Chand, T.R., Reddy, R.R., Rama Gopal, K., Siva Sankara Reddy, L., Narasimhulu, K. and Raghavendra Kumar, K. (2007) Black carbon aerosols and gaseous pollutants in an urban area in North India during a fog period. Atmospheric Research, 85: 209-216. 
Badwi, M.I. and Al-Hosary, M.A. (1993) Study of air quality at central area near the Holy Mosque, Makkah City. Final report submitted to Hajj research center (Arabic text).

Barros, N. (1999) Poluicão Atmosférica por foto-oxidantes: o ozono troposférico naregião de Lisboa', PhD thesis, Universidade de Aveiro, Aveiro.

Borbon, A., Locoge, N., Vellerot, M., Galloo, J.C. and Guillermo, R. (2002) Characterization of NMHCs in a French urban atmosphere: overview of the main sources. The Science of Total Environment, 292: 177-191.

Brewer, D.A., Olgiaruso, M.A., Aygustson, T.R. and Levine, J.S. (1984) The oxidation of isoprene in the troposphere: mechanism and model calculations. Atmos. Environ., 18: 27232744.

Brönnimann, S., Buchmann, B. and Wanner, H. (2002) Trends in near-surface ozone concentrations in Switzerland: the 1990''. Atmos. Environ. 36: 2841-2852.

CARB (2006) Emission Data by Region (Statewide).California Air Resources Board.Accessed August 2007 from < http:// www.arb.ca.gov/ei/emissiondata.htm>.

Carslaw, D.C. and Beevers, S.D. (2004) Investigating the potential importance of primary NO2 emissions in a street canyon. Atmospheric Environment, 38: 3585-3594.

Carslaw, D.C. and Beevers, S.D. (2005) Development of an urban inventory for road transport emissions of $\mathrm{NO}_{2}$ and comparison with estimates derived from ambient measurements. Atmospheric Environment, 39: 2049-2059.

Crutzen, P.J. (1974) Photochemical reactions initiated by and influencing ozone in unpolluted tropospheric air. Tellus, 26: 47-56.

Crutzen, P.J., Heidt, L.E., Krasnec, J.P., Pollack, W.H. and Seiler, W. (1979) Biomass burning as a source of atmospheric gases $\mathrm{CO}, \mathrm{H}_{2}, \mathrm{~N}_{2} \mathrm{O}, \mathrm{NO}, \mathrm{CH}_{3} \mathrm{Cl}$, and $\mathrm{COS}$. Nature, 282: 253-256.

Derwent, R.G., Davis, T.J., Delaney, M., Dollard, G.J., Field, R.A., Dumitrean, P., Nason, P.D., Jones, B.M.R. and Pepler, S.A. (2000) Analysis and interpretation of the continuous hourly monitoring data for $26 \mathrm{C} 2-\mathrm{C} 8$ hydrocarbons at 12 United Kingdom sites during 1996. Atmospheric Environment, 34: 297-312.

Derwent, R.G., Jenkin, M.E., Saunders, S.M., Pilling, M.J., Simmonds, P.G., Passant, N.R., Dollard, G.J., Dumitrean, P. and Kent, A. (2003) Photochemical ozone formation in North West Europe and its control. Atmos. Environ., 37: 1983-1991.

DRSCH (Directory of RefikSaydam Center of Hygiene) (2006) Research Directorate of Environmental Health. Data downloaded in January; 2006). website: www.rshm.saglik.gov.tr.

Dueñas, C., Fernández, M.C., Cañete, S., Carretero, J. and Liger, E. (2002) Assessment of ozone variations and meteorological effects in an urban area in the MediterraneanCoast. Science of the Total Environment, 299: 97-113.

Durana, N., Navazo, M., Go'mez, M.C., Alonso, L., Garcı'a, J.A., Ilardia, J.L., Gangoiti, G. and Iza, J. (2006) Long term hourly measurement of 62 non-methane hydrocarbons in an urban area: main results and contribution of non-traffic sources. Atmospheric Environment, 40: $2860-2872$.

European Commission (1997) Position paper on air quality: nitrogen dioxide. Working Group on Nitrogen Dioxide, EC. $<$ http://ec.europa.eu/environment/air/pdf/pp_no2.pdf $>$.

Finlayson-Pitts, B.J. and Pitts, J.N. Jr. (2000) Chemistry of the upper and lower atmosphere. Academic, London.

Gregory, S. (1963) Statistical methods and the Geographer, first ed. Longmans, London.

Guicherit, R. and Roemer, M. (2000) Tropospheric ozone trends. Chemosphere-Global Change Science, 2: 167-183.

Gupta, A.K., KakoliKarar, S. Ayoob and Kuruvilla John (2008) Spatio-temporal characteristics of gaseous and particulate pollutants in an urban region of Kolkata, India. Atmospheric Research, 87: 103-115. 
Gurjar, B.R., Butler, T.M., Lawrence, M.G. and Lelieveld, J. (2008) Evaluation of emissions and air quality in megacities. Atmos. Environ., 42: 1593-1606.

Han, X. and Naeher, P.L. (2006) A review of traffic-related air pollution exposure assessment studies in the developing world. Environment International, 32: 106-120.

Harrison, R.M. and Perry, R. (1986) 'Handbook of Air Pollution Analysis', second ed. Chapman and Hall, London, New York.

Hatakeyama, S., Izumi, K., Fukuyama, T., Akimoto, H. and Washida, N. (1991) Reactions of $\mathrm{OH}$ with a-pinene and h-pinene oxidation of terpenes. J. Geophys. Res., 96: 959-990.

Henry, J.G. and Heinke, G.W. (1996) Environmental Science and Engineering (2nd Edition), Prentice-Hall Inc., USA,

Holgate, S.T., Samet, J.M., Koren, H.S. and Maynard, R.L. (1999) Air pollution and health. Academic, London.

Jenkin, M.E. and Clemitshaw, K.C. (2000) Ozone and other secondary photochemical pollutants: chemical processes governing their formation in the planetary boundary layer. Atmospheric Environment, 34: 2499-2527.

Jockel, P., Brenninkmeijer, C.A.M. and Crutzen, P.J. (2003) A discussion on the determination of atmospheric $\mathrm{OH}$ and itstrends. Atmos. Chem. Phys., 3: 107-118.

Jraiw, K. (2002) Cleaning the air: Vehicular emission in the People Republic of China (PRC). ADB 35th Annual Meeting, 12 May, Shanghai International Convention Center, PRC.Available at:http://www.adb.org/AnnualMeeting/2002/media/vehicle_emissions.asp.

Khoder, M.I. (2002) Atmospheric conversion of sulfur dioxide to particulate sulfate and nitrogen dioxide to particulate nitrate and gaseous nitric acid in an urban area. Chemosphere, 49: 675-684.

Khoder, M.I. (2004) Atmospheric formation and occurrence of nitrous acid and its role in the formation of ozone in the city centre in Cairo, Egypt. Egyptian Journal of Chemistry, 47: 189-209.

Khoder, M.I. (2009) Diurnal, seasonal and weekdays-weekends variations of ground level ozone concentrations in an urban area in Greater Cairo. Environmental Monitoring and Assessment, 149: 349 - 362.

Latha, K.M. and Badarinath, K.V.S. (2003) Black carbon aerosols over tropical urban environment-a case study. Atmospheric Research, 69: 125-133.

Lei, H.C., Tanner, P.A., Huang, M.Y., Shen, Z.L. and Wu, Y.X. (1997) The acidification process under the cloud in Southwest China: observation results and simulation. Atmos. Environ., 31: 851-861.

Lewne, M., Cyrys, J., Meliefste, K., Hoek, G., Brauer, M., Fischer, P., Gehring, U., Heinrich, J., Brunekreef, B. and Bellander, T. (2004) Spatial variation in nitrogen dioxide in three European areas. Science of the Total Environment, 332: 217-230.

Liu, C.M., Xu, Z.L., Du, Y.G. and Guo, H.C. (2000) Analyses of volatile organic compounds concentrations and variation trends in the air of Changchun, the northeast of China. Atmospheric Environment, 34: 4459-4466.

Logan, J.A., Prather, M.J., Wofsy, S.C. and McElroy, M.B. (1981) Tropospheric chemistry: a global perspective. Journal of Geophysical Research, 86: 7210-7254.

Matsumoto, K., Naggo, I., Tanaka, H., Miyaji, H., Iida, K. and Ikebe, Y. (1998) Seasonal characteristics of organic and inorganic species and their size distributions in atmospheric aerosols over the northwest Pacific Ocean. Atmos. Environ., 32: 1931-1946.

Matsumoto, K. and Tanaka, H. (1996) Formation and dissociation of atmospheric particulate nitrate and chloride: an approach based on phase equilibrium. Atmos. Environ., 30: 639648.

Mauzerall, D.L., Sultan, B., Kim, N. and Bradford, D.F. (2005) NOx emissions from large point sources: variability in ozone production, resulting health damages and economic costs. Atmospheric Environment, 39: 2851-2866. 
Na, K. and Kim, Y.P. (2001) Seasonal characteristics of ambient volatile organiccompounds in Seoul, Korea. Atmospheric Environment, 35: 2603-2614.

Özden, Ö., Döğeroğlu, T. and Kara, S. (2008) Assessment of ambient air quality in Eskişehir, Turkey. Environment International, 34: 678-687.

Pereira, M.C., Alvim-Ferraz, M.C.M. and Santos, R.C. (2005) Relevant aspects of air quality in Oporto (Portugal): $\mathrm{PM}_{10}$ and $\mathrm{O}_{3}$. Environmental Monitoring and Assessment, 101: 203221.

PORG (1997) Ozone in the United Kingdom.Fourth report of the UK Photochemical Oxidants Review Group, Department of the Environment, Transport and the Regions, London. Published by Institute of Terrestrial Ecology, Bush Estate, Penicuik, Midlothian, EH26 0QB, UK. ISBN: 0- 870393-30-9, available at www.aeat.co.uk/netcen/airqual/ reports/home.html.

Poulida, O., Dickerson, R.R., Doddridge, B.G., Holland, J.Z., Wardell, R.G. and Watkins, J.G. (1991) Trace gas concentrations and meteorology in rural Virginia: Ozone and carbon monoxide. Journal of Geophysical Research, 96: 22461-22475.

Pudasainee, D., Sapkota, B., Shrestha, M.L., Kaga, A., Kondo, A. and Inoue, Y. (2006) Ground level ozone concentrations and its association with NOx and meteorological parameters in Kathmandu valley, Nepal. Atmos. Environ., 40: 8081-8087.

Qin, Y., Walk, T., Gary, R., Yao, X. and Elles, S. (2007) $\mathrm{C}_{2}-\mathrm{C}_{10}$ non-methane hydrocarbons measured in Dallas, USA dseasonal trends and diurnal characteristics. Atmospheric Environment, 41: 6018-6032.

Rao, T.V.R., Reddy, R.R., Sreenivasulu, R., Peeran, S.G., Murthy, K.N.V., Ahammed, Y.N., Gopal, K.R., Azeem, P.A., Sreedhar, B. and Sunitha, K. (2002a) Air space pollutants CO and NOx level at Anantapur (semi-arid zone), Andhra Pradesh. J. Indian Geophys. Union, 3: $151-161$.

Rao, T.V.R., Reddy, R.R., Sreenivasulu, R., Peeran, S.G., Murthy, K.N.V., Ahammed, Y.N., Gopal, K.R., Azeem, P.A., Sreedhar, B. and Badarinath, K.V.S. (2002b) Seasonal and diurnal variations in the levels of NOx and CO trace gases at Anantapur in Andhra Pradesh. J. Indian Geophys. Union, 3: 163-168.

Sadanga, Y., Matsumoto, J. and Kajii, Y. (2003) Photochemical reactions in the urban air: recent understandings of radical chemistry. Journal of Photochemistry and Photobiology, 4: 85-104.

Saito, S., Ippei Nagao and Hiroshi Kanzawa (2009) Characteristics of ambient $\mathrm{C}_{2}-\mathrm{C}_{11}$ nonmethane hydrocarbons in metropolitan Nagoya, Japan. Atmospheric Environment, 43: 4384-4395.

Seinfeld, J.H. and Pandis, S.N. (1998) Atmospheric Chemistry and Physics: From Air Pollution to Climate Changes. John Wiley \& Sons, USA.

Seinfeld, J.H. and Pandis, S.N. (2006) Atmospheric Chemistry and Physics: from Air Pollution to Climate Change. Wiley, New York, pp. 204-283.

Shrestha, R.M., Anandarajah, G., Adhikari, S., Jiang, K.and Zhu, S. (2005) Energy and environmental implications of NOx emission reduction from the transport sector of Beijing: a least-cost planning analysis. Transp Res Part D Transp Environ., 10: 1-11.

Thompson, A.M. (1992) The oxidizing capacity of the Earth's atmosphere: probable past and future changes. Science, 256: 1157-1168.

Tie, X., Brasseur, G., Zhao, C., Granier, C., Massie, S., Qin, Y., Wang, P.C., Wang, G.L. and Yang, P.C. (2006) Chemical characterisation of air pollution in Eastern China and the Eastern United States. Atmos. Environ., 40: 2607-2625.

UK Air Quality Archive (2008) UK Air Quality Archive homepage. http://www.airquality.co.uk/archive/index.php.

US EPA (2008) US Environmental Protection Agency home page.http://www.epa.gov.

Vingarzan, R. and Taylor, B. (2003) Trend analysis of ground level ozone in the greater Vancouver/Fraser Valley area of British Columbia. Atmos. Environ., 37: 2159-2171. 
Wang, W.-X, Fa-he Chai, Kai Zhang, Shu-lan Wang, Yi-zhen Chen, Xue-zhong Wang and Ya-qin Yang (2008) Study on ambient air quality in Beijing for the summer 2008 Olympic Games. Air Qual. Atmos. Health, 1: 31-36.

Wang, X., Lu, W., Wang, W. and Leung, A. (2003) A study of ozone variation trend within area of affecting human health in Hong Kong. Chemosphere, 52: 1405-1410.

Warneck, P. (1988) Chemistry of Natural Atmosphere. Academic, San Diego, CA.

WHO (World Health Organisation) (2003).Health aspects of air pollution with particulate matter, ozone and nitrogen dioxide. Report on a WHO Working Group. Bonn, Germany, 13-15 January 2003. <http://www.euro.who.int/document/ e79097.pdfs.

WHO (World Health Organisation) (2005). WHO air quality guidelines global update 2005. Report on a WHO Working Group. Bonn, Germany, 18-20 October 2005. < http:// www.euro.who.int/Document/E87950.pdfs.

WHO (World Health Organization) (1997). Nitrogen oxides (2nd ed.), environmental health criteria 188.Geneva (Switzerland): World Health Organization, International Programme on Chemical Safety, 1997.

Yacob, A.A. (2000) Air quality inside the Holy Mosque (Chemical and Microbial content). Final report submitted to Institute of the Custodian of the two Holy Mosque, Aum Alqura University (Arabic text). http://www.eia.doe.gov/emeu/cabs/saudenv.html.

Yang, K.L., Ting, C.C., Wang, J.L., Wingenter, O.W. and Chan, C.C. (2005) Diurnal and seasonal cycles of ozone precursors observed from continuous measurement at an urban site in Taiwan. Atmospheric Environment, 39: 3221-3230.

Zabalza, J., Ogulei, D., Elustondo, D., Santamaría, J.M., Alastuey A., Querol, X. and Hopke, P.K. (2007) Study of urban atmospheric pollution in Navarre (Northern Spain). Environ. Monit. Assess., 134: 137-151

Zhang, R.W., Lei, X., Tie, P. and Hess (2004) Industrial emissions cause extreme diurnal urban ozone variability. Proceedings of National Academic Science USA, 101: 6346-6350.

Zimmerman, P.R., Chatfield, R.B., Fishman, J., Crutzen, P.J. and Hanst, P.L. (1978) Estimates of the production of $\mathrm{CO}$ and $\mathrm{H}_{2}$ from the oxidation of hydrocarbon emissions from vegetation. Geophys. Res. Lett., 5: 679- 682. 


\section{دراسة حركة واتجاهات تركيزات الملوثات الهوائية الغازية في أجواء المدينة المنورة، المنطقة المركزية، المملكة العربية السعودية}

\section{هشام بن عبد الله الجيلاني}

قسم العلوم البيئية، كلية الأرصاد والبيئة وزراعة المناطق الجافة

جامعة الملك عبد/لعزيز، جدة - المدلكة العربية السعودية

الستخلص. تم قياس تركيزات أول أوكسيد النيتروجين، وثاني أوكسيد

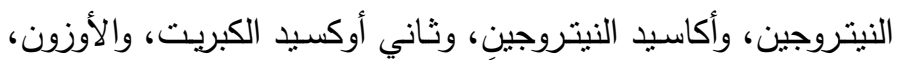

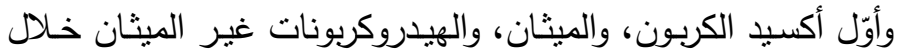

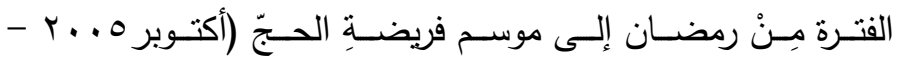

يناير Y + . r) في المنطقة الحضريةِ بالمدينة المنورة، المملكة العربية

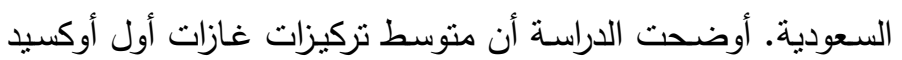

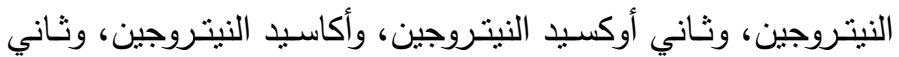

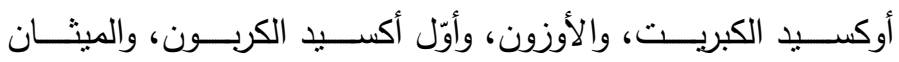

والهيدروكربونات غير الميثان كانت 00 ., •، و • • ., •، و و 90 ., •.

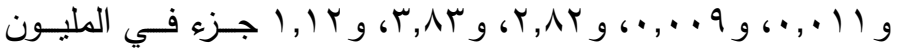

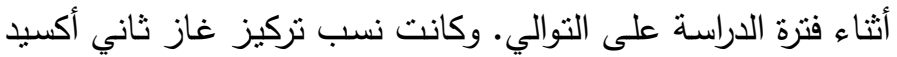

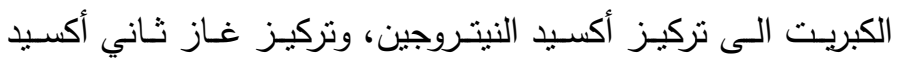

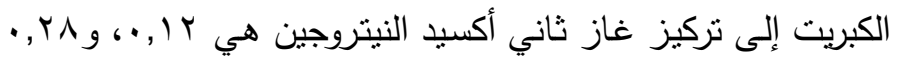

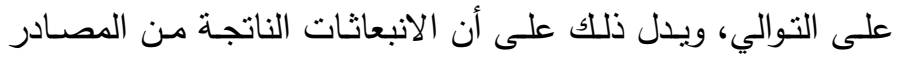

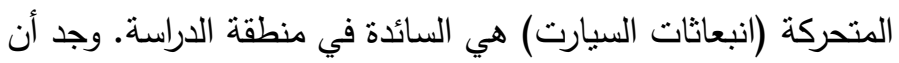

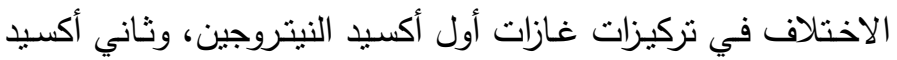

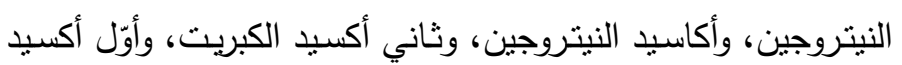


الكربون، والهيدروكربونات غير الميثان خلال ساعات اليوم أثناء فترةٍ

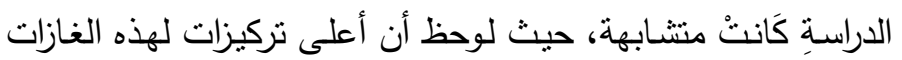

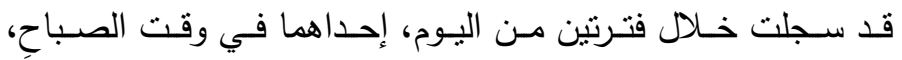

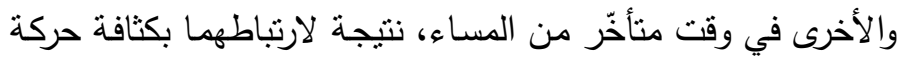

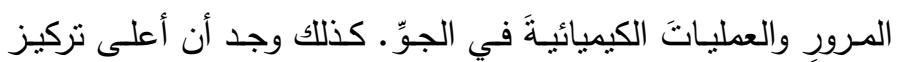

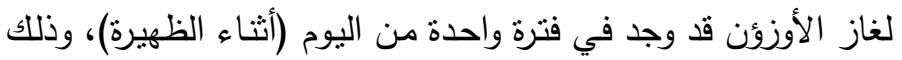

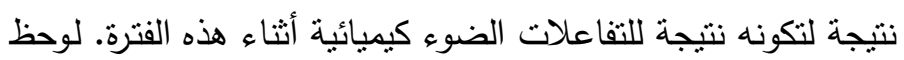

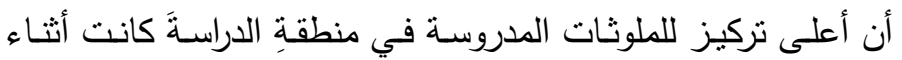

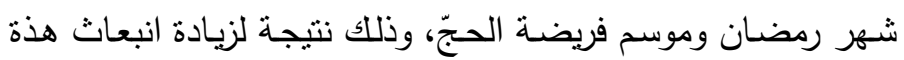

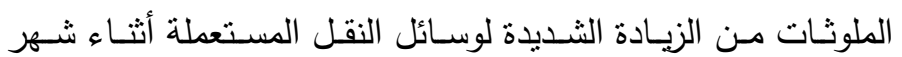

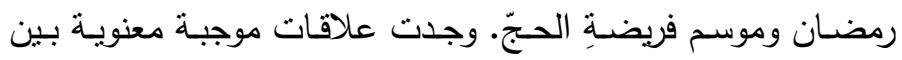

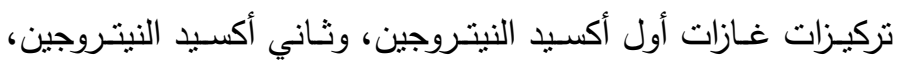

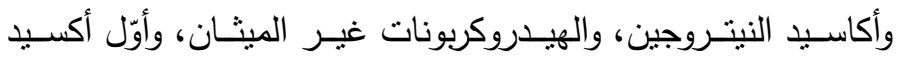

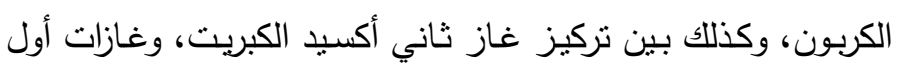

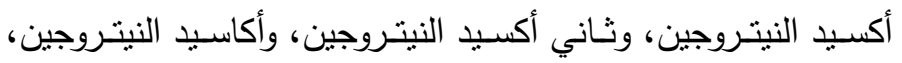

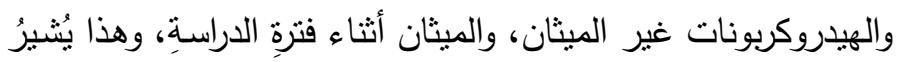

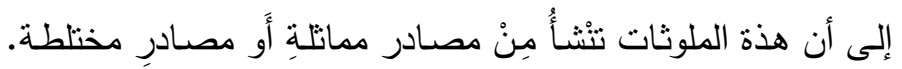

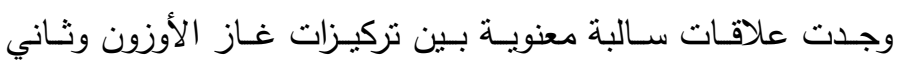

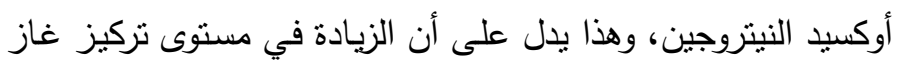
الأوزون مرتبط بالهبوط في نركيز غاز ثاني أوكسيد النيتروجين. الكلمات الدالة: ملوثات الهواء الغازيـة، أول أكسبد النيتروجين، ثناني

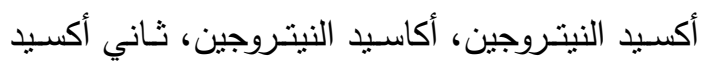

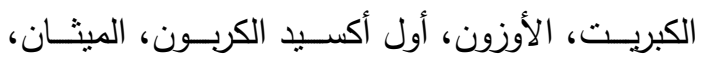
الهيدروكربونات غير الميثان، المدينة المنورة، المملكة الونة العبدة العبدة العربية السعودية. 